\title{
Between Vision and Scandal. Analysis of Bernie Sanders and Donald Trump's Language During the American Presidential Primaries
}

\author{
Między wizją a skandalem. Analiza języka Berniego Sandersa \\ oraz Donalda Trumpa w czasie amerykańskich prawyborów
}

\section{- Abstrakt •}

Celem artykułu jest analiza języka politycznego Berniego Sandersa oraz Donalda Trumpa w czasie prawyborów prezydenckich w USA w 2015/2016 r. Politologicznej interpretacji zostaje poddana narracja obydwu kandydatów w celu ukazania nie tylko jej zwartości ideowopolitycznej, ale także znaczenia wyborczego. Autor artykułu zwraca ponadto uwagę na szczególny charakter nie tylko opisywanych prawyborów Partii Demokratycznej i Partii Republikańskiej, ale także opisywanych kandydatów. Sanders oraz Trump reprezentują nie tylko lewicową i prawicową populistyczną odpowiedź na 8 lat prezydentury Baracka Obamy, ale są także głównymi kandydatami amerykańskiego antyestablishmentu, co z łatwością możemy zaobserwować w ich politycznym języku.

Słowa kluczowe: demokracja; socjalizm; prawica; lewica; populizm

\section{- Abstract •}

The aim of this paper is to analyse the political language of Bernie Sanders and Donald Trump during the 2015/2016 presidential primaries in the United States. The narrative delivered by both candidates is interpreted from the perspective of political science in order to show not only its ideological and political content, but also the electoral significance. The author stresses not only the highly particular nature of the analyzed primaries of the Democratic and Republican Parties, but also discusses the character of the candidates themselves. Sanders and Trump not only represented the populist answer to the 8 years of presidency of Barack Obama (on the left and right side of the political spectrum respectively), but were also the main candidates of the American anti-establishment circles, which becomes very clear in the analysis of their political language.

Keywords: democracy; socialism; right-wing politics; left-wing politics; populism 
Electoral campaigns in the United States are the subject of innumerable studies by political scientists from around the world. In particular, those researching political marketing see the US as a birthplace of many innovations and a source of interesting case studies. It is worth noting that the American elections also provide a lot of material for analysis of the language of politics. The phrase "Ask not what your country can do for you, ask what you can do for your country" spoken by John Fitzgerald Kennedy in 1961, or Bill Clinton's slogan "It's the economy, stupid" from the 1992 presidential campaign will probably remain forever among key examples studied in handbooks on the language of politics.

The outbreak of the financial and economic crisis in the United States in 2008 significantly affected not only the global economic situation, but also the political arena in the US. The election of Barack Obama as 44. US President in 2008 and his reelection 4 years later were closely related to the deteriorating situation in the labor market, collapse of the real estate market and the increase in social inequalities in the US. Also the following 2016 electoral campaign was taking place in the context of a crisis. The primaries in the Democratic Party and the Republican Party were of an unprecedented nature. The debates of candidates battling for the nomination of these parties as a presidential candidate attracted the attention of millions of Americans, and the language used by the contenders was often a veritable novelty. The author of the present article uses the case studies of Bernie Sanders, fighting for the nomination of the Democratic Party, and Donald Trump, battling to be nominated as a presidential candidate by the Republican Party to present this broader phenomenon. For this purpose, the author used the qualitative analysis of discourse and content as well as a comparative analytical method. Political speeches of the aforementioned candidates, content published on their websites and in social media profiles, as well as appearances in debates and journalistic programs have all been analyzed. The study also has interdisciplinary, intertextual and interdiscursive value ${ }^{1}$. The first aspect is evidenced by the multiplicity of perspectives offered as part of the analysis, the second refers to connections between individual texts (content), and the third describes interactions between particular discourses. In addition, as Ruth Wodak observes: "The manifold roots of critical discourse analysis lie in rhetoric, text linguistics, anthropology, philosophy, sociopsychology, cognitive science, literary studies and sociolinguistics, etc." (Wodak, 2011). Therefore, the analysis of political messages of Sanders and Trump requires reaching out into multiple fields of research in both humanities and social sciences.

${ }^{1}$ Such tri-dimensional nature of qualitative discourse analysis is referenced by, inter alia, Wodak (2011). 
Analysis of the language of politics using the examples of Bernie Sanders and Donald Trump during the primaries of the Democratic and the Republican Party, respectively, is viewed as particularly important by the author for a number of reasons $^{2}$. Firstly, since 2008, we have not witnessed such an even fight for the presidential nomination between individual candidates of both parties, which resulted in unexpected twists and turns in the campaign - and in richness of language used by all contenders for the aforementioned nomination. Secondly, the described primaries basically "disenchanted" many principles and unwritten rules of the American political life - this applied to both the so-called "political correctness" as well as the customary use of certain ideological terminology in the American political system. Bernie Sanders was the first national-level candidate in decades describing himself openly as a democratic socialist, while socialism is very often seen by the US mainstream as a synonym of communism or Marxism-Leninism. The above is the effect of the Cold War ideological battle between the US and the USSR, combined with antipathy of the Democratic Party itself for any competing left-wing political parties on the American soil ${ }^{3}$. Donald Trump, in turn, used aggressive and very often offensive language, not only against his competitors in the race for the nomination of the Republican Party (Donald Trump's Top 20 insults that are True) but also to describe large social groups, such as the Hispanic community. Thirdly, the language of Sanders and Trump both carries an important political message in relation to the American political establishment. Both politicians often spoke out explicitly against the corruption of American politics, its base nature and the harmful dependence of the legislative and the executive on lobbyists and donors. In a sense, they embodied a left-wing and right-wing reaction not only to the 8-year presidency of Barack Obama, while also representing two different responses to the reality of the US post-crisis. The phenomenon of Sanders and Trump is, according to the author of the paper, also connected with the new meaning (new, as it suddenly became part of mainstream media communications) given to two bottom-up, populist political movements, namely Tea Party and Occupy Wall Street. The conservative-libertarian demands of the Tea Party are fully articulated by Donald Trump, who declared himself in favor of low taxes, radical reduction in public spending, and the abolition of Barack Obama's health

${ }^{2}$ Despite the victory of Hilary Clinton in the Democratic Party primaries, the author of the paper deliberately chose the language of Bernie Sanders as the object of analysis. Sanders' language is a left-wing version of the anti-establishment discourse, which makes this a fitting case study to compare with the language used by Donald Trump.

${ }^{3}$ It should be mentioned however that all socialist groupings and parties in the US were considered enemies by both Democrats and Republicans alike (Sombart, 2004). 
reforms, known as ObamaCare (Full Speech: Donald Trump Speaks at the SC Tea Party Convention (1 16 16)). In turn, Bernie Sanders, speaking about unpaid university education and the harmful influence of Wall Street on Washington's political arena showed himself clearly in favor of postulates of the Occupy Wall Street movement. In addition, one of the best-known and widest-spread slogans of the movement, "We are the 99\%" (Rydlinski, 2012) was the foundation of Sanders' narrative in the campaign (A Rigged Economy: This Is How it Works/Bernie Sanders, (Democratic Debate) Bernie Sanders explains Democratic Socialism) ${ }^{4}$. To summarize, both Donald Trump and Bernie Sanders not only brought a fundamental symbolic change to the American right- and left-wing politics, but also added a new dimension to the political battle .

The vision and scandal leitmotifs as signaled in the title of this paper are the result of the author thus categorizing the political language of Bernie Sanders and Donald Trump, which embody two totally different political-ideological and image design concepts. Sanders tried to present himself as a socialist dreamer and visionary, while Trump not only tried to increase his popularity and recognition through scandal, but also attempted to transform the politically incorrect opinions of "ordinary" Americans about main issues plaguing USA into items on his political agenda.

\section{Sanders as a Socialist Visionary}

Bernie Sanders, as already mentioned, described himself as a socialist. He stressed repeatedly that he uses the term as it is understood in democratic socialism a program which in his opinion is closest to becoming reality in the Scandinavian welfare states. He stated, inter alia: "And if we know that in countries, in Scandinavia, like Denmark, Norway, Sweden (...) In those countries, health care is the right of all people. And in those countries, college education, graduate school is free. In those countries, retirement benefits, child care are stronger than in the United States of America, and in those countries, by and large, government works for ordinary people in the middle class, rather than, as is the case right now in

\footnotetext{
${ }^{4}$ One should stress that already in 2011, Bernie Sanders - still as a senator from the state of Vermont - supported the Occupy movement protests (Bernie Sanders on Occupy Wall Street Protests - Countdown w/ Keith Olbermann 9/29/11).

5 To reiterate using Chantal Mouffe's phrasing, they have brought antagonistic confrontation into the political debate, which is for Mouffe a prerequisite of true democracy (Mouffe, 2008).
} 
our country, for the billionaire class" (Bernie Sanders on what America can learn from "socialist" counties). He also often pointed out that his socialist views mean dissent not only for the enormous and uncontrolled influence of corporations and capitalists on American politics, but also for the entire system described as "casino capitalism"6. During the first debate of the Democratic Party candidates for presidential nomination held on October 13, 2015 in Las Vegas, when asked by the facilitator if he would describe himself as a capitalist, he replied: "Do I consider myself part of the casino capitalist process by which so few have so much and so many have so little by which Wall Street's greed and recklessness wrecked this economy? No, I don't. I believe in a society where all people do well. Not just a handful of billionaires" ((Democratic Debate) Bernie Sanders explains Democratic Socialism). In that same debate, Bernie Sanders described the main problems faced by the United States, the selection of which was closely related to his political leftist vision of the future. He mentioned the reducing importance and size of the American middle class, extension of working hours with simultaneously falling wages, the new prosperity and results of hard work of the entire nation being consumed by the upper $1 \%$ of American society, corruption of the US political system due to possibility of unlimited funding of politicians by millionaires and billionaires, adverse impact of climate change on the natural environment, the unimaginable explosion of the number of prisoners and disproportionate unemployment especially among young African Americans and Hispanics (Bernie Sanders Highlights First Democratic Debate 2015). Symptomatic for the language of Bernie Sanders is the question of a comprehensive description of the American reality, in which various components make a cohesive whole. In addition, this message was addressed to many social groups: the middle class, working families, the unemployed. It is the language of both the leftist intelligentsia and the working class, of people guided in their political choices by both socio-economic arguments and a post-material view of the world.

Another important characteristic easily noticeable in the political language of Bernie Sanders is his attachment to grassroots democratic processes and their political significance. He referenced these issues during the debate with his main contender for the Democratic Party nomination, Hilary Clinton on February 5, 2016 in New Hampshire: "Millions of Americans are giving up on the political process. And they're giving up on the political process because they understand the economy is rigged (...) And then sustaining that rigged economy is a corrupt

\footnotetext{
${ }^{6}$ Significance and connotations of the term have been in detail analysed in Polish-language literature by Tadeusz Kowalik (Kowalik, 2009).
} 
campaign finance system undermining American democracy, where billionaire, Wall Street, corporate America can contribute unlimited sums of money into super PACs ${ }^{7}$ and into candidates. Our job, together, is to end a rigged economy, create an economy that works for all, and absolutely overturn Citizens United. One person, one vote. That's what American democracy is about" (FULL Democratic Debate: Bernie Sanders, Hillary Clinton Face Off In New Hampshire). In his campaign Sanders built on this critique and turned it into a highly useful tool and asset. Through a system of small contributions, he allowed millions of Americans to participate in funding of his campaign. On Sanders's candidate website, the pride of place was given to information on how to help finance his campaign and contribute the amount of 10,35 or 100 USD (Bernie Sanders $\mid$ I stand with Bernie). He stressed at multiple occasions that he does not accept funds from millionaires and billionaires ${ }^{8}$, stating firmly that "you can't change a corrupt system by taking its money" (A Rigged Economy: This Is How it Works). As one can see, Sanders tried to use language based on the moral conviction that accepting contributions from corporate moguls and large businesses is destructive for the American democracy. He also used this argument in his clashes with Hilary Clinton, suggesting that through her "traditional" campaign financing model she not only was not offering a new, more transparent approach to fundraising, but also hinting that she had not always acted entirely honestly in the past. On February 28, 2016 in Oklahoma City, Bernie Sanders drew attention to an uncomfortable facet of the relationship between Hillary Clinton and the corporate America: "Secretary Clinton has given some speeches to Wall Street where she's paid over $\$ 200,000$ a speech. This is what I think, if you're going to get paid $\$ 200,000$ for a speech, it must be a pretty damn good speech. And if it's such a good speech, you gotta release the transcripts and let everybody see them" (Release the Transcripts). The effect of using this language is almost an organic, natural creation of the image of an independent candidate, representing the "average Joes" and "ordinary" Americans who through their numerous contributions become natural participants in his campaign. Moreover, Sanders' critical assessment of financing of politics in America was reflected positively in the public's opinion of him as a candidate. For example, Sarah Silverman, an American satirist who publicly supported his candidacy in Los Angeles, stated the following: "Where other candidates are getting gigantic sums of money from

${ }^{7}$ PAC - Political Action Committee. A tool for financing of electoral campaigns of US politicians by donors. The term Super PAC refers to the possibility of practically unlimited money transfers for the benefit of individual candidates.

${ }^{8}$ In fact, his campaign posters bore the annotation Paid for by Bernie 2016. Not the billionaires (Bernie for President). 
billionaires in exchange for compromising favors, Bernie is not for sale" (Sarah Silverman Introduces Bernie Sanders in L.A.).

What can be described as Bernie Sanders' own politics of history and the language he uses to counter allegations of naivety and socialistic lean of his political program are equally worth noting. To this end, Sanders reached for the example of one of the most well-known and respected US presidents in history, namely Franklin Delano Roosevelt. During his public lecture on democratic socialism at Georgetown University in Washington on November 19, 2015 Sanders said: "Almost everything he proposed was called 'socialist'. Social Security, which transformed life for the elderly in this country was 'socialist'. The concept of the 'minimum wage' was seen as a radical intrusion into the marketplace and was described as 'socialist'. Unemployment insurance, abolishing child labor, the 40-hour work week, collective bargaining, strong banking regulations, deposit insurance, and job programs that put millions of people to work were all described, in one way or another, as 'socialist'. Yet, these programs have become the fabric of our nation and the foundation of the middle class" (Democratic Socialism and Foreign Policy). This example shows well how Sanders tried to deflect the arguments of his political opponents. A reference to Roosevelt was a tactical move, as this US president was particularly known for his visionary and above all effective plan to counteract unemployment during the Great Depression of the 1930s. Sanders did not only point out to his audience that his own political vision is based on achievements from the time of presidency of FDR, but placed it in a broader context of progressive ideas. He made a reference also to Martin Luther King, who in his activity fought not only for abolishment of racial discrimination in the US and equal rights for African Americans, but argued also in favour of fundamental changes to the American economy, which in his opinion resembled "socialism for the rich".

In all the above-mentioned examples, one can easily see that the language of Bernie Sanders is based on the moral conviction that the United States has failed to break with its corrupt system of financing of politics, which is the greatest threat to American democracy. In addition, Sanders relied on the belief that the US needs a radical change built on the concept of democratic socialism, completion of the emancipation processes, and basing the state's foundations on civic democratic movements in order to bring equality and inclusion back into politics. His language was consistent with the overall atmosphere of his campaign, which was centered around the idea of a real grassroots democracy?

9 Bernie Sanders' campaign staff even published a special electoral spot showing the extraordinary devotion of volunteers involved in his election campaign (It's a Revolution, Bernie Sanders). 


\section{Trump - A Scandalist}

The second interesting case study, particularly worth analyzing as part of the present paper devoted to modern populism and its implementation in political communications, is the language used in the Republican primaries by Donald Trump. Trump was an atypical candidate for many reasons. Firstly, he is not a professional politician, but an entrepreneur, billionaire, owner of many properties, hotels, restaurants and casinos, a global "business icon". Secondly, in a sense he is the very embodiment of the anti-politics movement. He is known for his critical words about the entire American political class - he claimed that "Politicians are all talk, no action" as well as "they run and they run, and they win and sometimes they lose and they keep running" (Donald Trump's Top 20 insults that are True). Thirdly, Trump continues to cross the boundaries of the so-called political correctness, creating an atmosphere of scandal that puts him not only in the position of a troublemaker but, more importantly, also of a person who has the courage to say what "ordinary" Americans really think.

It is worth providing a few examples of how Donald Trump's language basically destroyed the habit of political correctness during his campaign in the last Republican primaries. One of the first widely discussed faux pas was his insulting remark about Hilary Clinton, the leading candidate in the Democratic Party primaries. In Trump's official account on Twitter, a following entry was published on April 16, 2015: "If Hillary Clinton can't satisfy her husband what makes her think she can satisfy America?" (Martosko, 2015). This remark was related to the famous 1998 scandal, in which it came to light that the then US President Bill Clinton, Hillary's husband, engaged in "other sexual activities" with the White House intern Monika Lewinsky. Trump seemed to suggest that Bill Clinton's cheating on his wife was associated with insufficient passion in their marital life. Another example was Donald Trump's crass remark about John McCain, one of the most experienced US senators, a former Republican candidate in the 2008 presidential election, and the icon of the American war in Vietnam. During the war, McCain was captured and tortured by the Vietnamese side. On July 18, 2015 in Iowa, Donald Trump said: "He's not a war hero. He was a war hero because he was captured. I like people who weren't captured". (Donald Trump questions if $M c$ Cain is a 'war hero'). This opinion provoked outrage not only of the Republican Party itself, as McCain is seen as one of the greatest symbols of heroism among the Republican circles, but also of vast majority of the American public opinion, who perceived this experienced senator from Arizona in exactly the same manner. Trump's insulting remark was retaliation for the fact that this former Republican 
candidate for the office of the President of the United States repeatedly criticized Donald Trump for his populism and lack of preparation to perform the highest public functions in the country. Another noteworthy example was Trump's offensive comment about Mexican immigrants at the inauguration of his presidential campaign in New York on June 16, 2015. Trump stated: "When Mexico sends its people, they're not sending their best. They're sending people that have lots of problems, and they're bringing those problems with us. They're bringing drugs. They're bringing crime. They're rapists. And some, I assume, are good people" (Donald Trump Presidential Announcement Full Speech 6/16/15). It is evident from this example that Trump intentionally tried to paint the issue of migration from Latin America to the USA in a negative light, using generalizations and stereotypes. The question of illegal migration is a problematic matter especially in the southern states, where the Republicans are in the lead politically. The author is of the opinion that Trump deliberately used this issue to give rise to a public scandal in order both to publicize his candidacy and to gain support among the traditional southern Republican electorate. Another controversial idea employed by Trump to help him consolidate the traditional right-wing electoral segment was the postulate of a total ban on Muslims entering the United States until - using the language of the analysed candidate himself - "our country's representatives can figure out what the hell is going on" (Donald Trump wants, total' halt to Muslims coming to US - BBC News). The phrase was part of a speech held in South Carolina on December 8, 2015 a few days after the events in San Bernardino, California, during which assassins - most likely associated with the so-called Islamic State (ISIS) - have shot 14 people. This exemplifies the deliberate use by Trump of rhetoric equating Muslims = terrorists $=$ jihadists in order to polarize public opinion.

In addition to arousing great emotion by openly giving his personal opinions during speeches and interviews, Donald Trump also used very characteristic language during electoral debates with other contenders in the Republican Party preliminaries. During one of them, which took place on February 15, 2016 in South Carolina, he attacked both former US President George W. Bush and his brother Jeb, who, like Trump, was in the running for the Republican nomination. Trump said: "Obviously, the war in Iraq was a big, fat mistake. All right? Now, you can take it any way you want, and it took - it took Jeb Bush, if you remember at the beginning of his announcement, when he announced for president, it took him five days. He went back, it was a mistake, it wasn't a mistake. It took him five days before his people told him what to say, and he ultimately said, "it was a mistake". The war in Iraq, we spent $\$ 2$ trillion, thousands of lives, we don't even have it. Iran 
has taken over Iraq with the second-largest oil reserves in the world. Obviously, it was a mistake. George Bush made a mistake. We can make mistakes. But that one was a beauty. We should have never been in Iraq. We have destabilized the Middle East" (Full CBS News South Carolina Republican Debate). He added that the American intervention in Iraq was based on a lie regarding the alleged existence of weapons of mass destruction, which was disproved. Furthermore, in response to Jeb Bush' comment that while Donald Trump was still involved in creating a reality TV show, his brother George W. Bush was building a security system of the United States, Trump riposted: "The World Trade Center came down during your brother's reign, remember that" (Full CBS News South Carolina Republican Debate). As this instance shows, Trump's language is both uncompromising and judgmental, and demonstrates a varied scale of radicalism - this was also the case with the examples described earlier in the paper.

Another extremely important element in the analysis of Donald Trump's language is the question of honesty of speech. Like Bernie Sanders, Trump criticized the influence of lobbyists and the financial world on politicians. However, he used entirely different argumentation. He said that as a businessman, he knew exactly how the system looked like from the position of a person who had taken advantage of its regrettable practices and loopholes in order to obtain politicians' help in achieving his particular interests. Trump asserted: "I know how the system works better than anybody. Many of the people who gave to Jeb and to Hillary and to anybody else, they are friends of mine or enemies of mine. But they are people I know. These are not people that are doing it because they like the color of his hair, believe me. These are highly sophisticated killers. And when they give $\$ 5$ million dollars or $\$ 2$ million or $\$ 1$ million to Jeb, they have him just like a puppet. He'll do whatever they want. He's their puppet. Believe me (...) I had yesterday a lobbyist call me up. It's a friend of mine. Good guy. Smart as hell. He's for his client. I don't blame him. He said, 'Donald, I want to put five million dollars into your campaign'. I said, 'I don't need it; I don't want it.' He said, 'No, no, I want to put five million in...' I said, 'I don't want it. Because when you come back to me in two years and you want help for a company you are representing or a country that you are representing, I am going to do the right thing for the people of the United States and I don't want to have to insult you" (Donald Trump Expose How Politicians Are Controlled By The 1\%). In the above quote, one can see that Trump attempted to create an image of himself as an expert in the techniques of exerting financial pressure and manipulation, thanks to which he would know how to not give into such attempts as the President of the United States. He thus shaped the public perception of himself as an experienced person in the field 
of finance, a knowledgeable businessman who, if necessary, would employ his expertise in the field of lobbying against the "1\%", i.e. the corporate moguls.

Donald Trump's language is a highly particular case study. It is centered around the techniques of scandalizing the public, putting radical opinions into wide public circulation and making them a topic of discussion in almost all American homes. An interesting element is also the fact that Trump broke away from the traditional republican narrative, based - for example as it was in the case of Bush - on the concept of war on terrorism. Trump was, in fact, the first major candidate of this party who in such an open manner questioned the overall sense and objectives of anti-terrorist activities carried out by the Bush administration for two full terms.

\section{Language as a Socio-Political Reflection}

Analysis of the language of both Bernie Sanders and Donald Trump was intended to show how these two most characteristic and clearly defined candidates of both parties differed and how the anti-establishment political message functioned as part of their respective campaigns in the analyzed primaries. Sanders and Trump represent two extremes of the spectrum of American politics, but their narratives in the primaries both testified to the US democracy still being heavily influenced by the 2008 crisis and the end of the economic and financial status quo. Both represented the voice of protest, dissent and the need for change. Both also tried to make it clear to the Democrats and Republicans that the old order from before the collapse of Lehman Brothers as well as the attempt to create a new political and economic reality by Barack Obama were not viable options. In a sense, both these candidates were and still are leaders of two mutually hostile grassroots social movements, linked only by their aversion to "mainstream" politics.

The analyzed case studies can also be understood as the return of "politicalness" to the American public debate. After the period of belief in "the end of history" as announced by Francis Fukuyama (Fukuyama, 1989) and the advent of the post-political era, we are in fact witnessing the rebirth of importance of political antagonism. The presented electoral campaign not only showed the deepening divisions between republican and democratic voters in the ideological-symbolic dimension but, above all, showed that conflict is an immanent feature of democracy. As per theories of Chantall Mouffe and Carl Schmitt, the two described candidates have abandoned the perception of consensus as a value in itself (Mouffe, 2005). The time of only technocratic differences between the leftist and rightist 
candidates seems to be a thing of the past, and the political era of populism, both on the left and right side of the American political arena started for good in 2015 and 2016.

Both the "vision" painted by Bernie Sanders and the "scandal" of Donald Trump should, in the author's opinion, be subjected to a joint systemic analysis. The language of politics is a reflection of social emotions and frustrations that, if suppressed or ignored, can come back with redoubled strength. Both Europe and the United States are now witnessing large anti-establishment bottom-up movements springing among many social groups. The nature of politics and the public discourse is changing right in front of our eyes. More and more frequently, radical right-wing and extreme leftist groups and politicians come to the fore in the political arena. One should listen carefully to these voices because the history of mankind has already proven multiple times that a democracy that is deaf to seemingly naive and shallow populist slogans often falls victim to its own ignorance. Let us hope that this time the voice of dissent will be fully understood by the political elite. Otherwise, Karl Marx' saying about history repeating itself may turn out to be not so much intellectually interesting as politically dangerous.

\section{References:}

A Rigged Economy: This Is How it Works/Bernie Sanders. Retrieved from: https://youtu.be/ pnSQVixz7wg.

Bernie for President. Retrieved from: https://fiu-assets-2-syitaetz61hl2sa.stackpathdns. $\mathrm{com} /$ static/use-media-items/37/36340/full-1000x1000/571bc446/rally-sign-blueaug2015_1024x1024.jpeg?resolution=0.

Bernie Sanders Highlights First Democratic Debate 2015. Retrieved from: https://youtu.be/ ruq9rEKiEks.

Bernie Sanders, I Stand With Bernie. Retrieved from: https://berniesanders.com/?nosplash $=$ true.

Bernie Sanders on Occupy Wall Street Protests - Countdown w/Keith Olbermann 9/29/11. Retrieved from: https://youtu.be/g4x0xaGN6bA.

Bernie Sanders on What America Can Learn From "Socialist" Counties. Retrieved from: https://www.facebook.com/OccupyDemocrats/videos/938272469599141/.

Clinton Sanders - Debate February 52016 MSNBC [FULL] 2/4/16. Retrieved from: https://youtu.be/SBkWShXFcZ4.

Democratic Socialism and Foreign Policy/Bernie Sanders. Retrieved from: https://youtu.be/ eQcmzGIKrzg.

Donald Trump Expose How Politicians Are Controlled By The \%1. Retrieved from: https:// youtu.be/7DN8_3xdSAQ. 
Donald Trump Presidential Announcement Full Speech 6/16/15. Retrieved from: https:// youtu.be/q_q61B-DyPk.

Donald Trump Questions if McCain is a 'War Hero'. Retrieved from: https://youtu.be/H6H $\mathrm{Kc} 24 \mathrm{oUiE}$.

Donald Trump's Top 20 Insults That Are True. Retrieved from: https://youtu.be/_wWnBdM 8OpE.

Donald Trump Wants 'Total' Halt to Muslims Coming to US - BBC News. Retrieved from: https://youtu.be/mo_nYQ6ItWM.

Fukuyama, F. (1989). The End of History?. Retrieved from: http://www.wesjones.com/eoh. htm.

Full CBS News South Carolina Republican Debate. Retrieved from: https://youtu.be/Un3OhYs-tCE.

Full Democratic Debate: Bernie Sanders, Hillary Clinton Face Off In New Hampshire|MSN$B C$. Retrieved from: https://youtu.be/7jK2eIpj6-c.

Full Speech: Donald Trump Speaks at SC Tea Party Convention (1 16 16). Retrieved from: https://youtu.be/KN2diEFNac4.

It's a Revolution/Bernie Sanders. Retrieved from: https://youtu.be/ocwVHGbYb3c.

Kowalik, T. (2009). Kapitalizm kasyna. In: J. Kutuła (ed.) Kryzys. Przewodnik Krytyki Politycznej (p. 68-88). Warszawa: Wydawnictwo Krytyki Politycznej.

Martosko, D. (2015). Claim That Hillary Clinton, Can't Satisfy her Husband' Winds up on Donald Trump's Twitter Account After Staffer Retweets It. Retrieved from: http://www. dailymail.co.uk/news/article-3043861/Claim-Hillary-Clinton-t-satisfy-husbandwinds-Donald-Trump-s-Twitter-account-staffer-retweets-it.html.

Mouffe, Ch. (2005). On the Political. Londyn-Nowy Jork: Routledge

Mouffe, Ch. (2008) Polityczność. Przewodnik Krytyki Politycznej. Warszawa: Wydawnictwo Krytyki Politycznej.

Release the Transcripts/Bernie Sanders. Retrieved from: https://youtu.be/kZOMBNFCoNQ.

Rydliński, B. (2012). Specyfika ruchu „Occupy”. Athenaeum. Polskie Studia Politologiczne, 36, 302-314.

Sarah Silverman Introduces Bernie Sanders in L.A. Retrieved from: https://youtu.be/TvJ5vdIUksM.

Sombart, W. (2004). Dlaczego nie ma socjalizmu w Stanach Zjednoczonych. Warszawa: Wydawnictwo IFIS PAN.

Wodak, R. (2011). Wstęp. Badania nad dyskursem. In: R. Wodak, M. Krzyżanowski (ed.), Jakościowa analiza dyskursu w naukach społecznych (p. 11-48). Warszawa: Oficyna Wydawnicza ŁośGraf.

(Democratic Debate) Bernie Sanders explains Democratic Socialism. Retrieved from: https:// youtu.be/K7jlAZSGXf4. 